\title{
OS IMPACTOS AMBIENTAIS QUE UM GRANDE EVENTO OCASIONA NA REGIÃO EM QUE É REALIZADO E AS AÇÕES SUSTENTÁVEIS PARA MINIMIZÁ-LOS, NA VISÃO DE UM GESTOR DE EVENTOS
}

\author{
Eduardo Yuji Kinjo da Silva
}

Bacharel em Administração do Centro Universitário Metodista

\section{Andrea Sander}

Professora Mestre do Centro Universitário Metodista

\section{RESUMO}

Este artigo tem por finalidade mostrar os impactos ambientais que um grande evento ocasiona na região em que é realizado e as ações sustentáveis para minimizá-los, na visão de um gestor de eventos. A sustentabilidade tem sido um assunto debatido fortemente no século XXI por grandes empresas, que estão buscando aliar as suas atividades com ações que possam diminuir os impactos ambientais na natureza. Os eventos de grande porte movimentam a economia e modificam o ambiente da região em que são realizados, tornando-se atrativos para investidores, aqueles eventos que buscam diminuir os impactos ambientais na região que se realizam e mais do que isso, oportunizam melhorias de sustentabilidade que ficam de herança para a região. Pensando nisso, o pesquisador buscou identificar o perfil do público de um grande evento, identificou ações do planejamento de um evento sustentável ambientalmente na opinião de um gestor de eventos e por fim estudou os impactos ambientais que um grande evento proporciona na região em que é realizado e quais as ações sustentáveis que podem minimizá-los na visão do gestor de eventos. A pesquisa teve um caráter qualitativo-quantitativa e descritivo, baseada em uma coleta documental, observação, entrevistas realizadas com um gestor, e questionário para o público de grandes eventos. Os resultados obtidos mostraram como a questão da preocupação ambiental tem se mostrado presente 
dentro das organizações e no mercado global, atraindo investidores e modificando o comportamento dos consumidores e das atividades econômicas, porém, essa realidade ainda é pouco percebida pelo público que frequenta eventos que trabalham com a sustentabilidade.

PALAVRAS-CHAVE: Sustentabilidade. Eventos. Planejamento.

\section{THE ENVIRONMENTAL IMPACTS OF A GREAT EVENT IN THE REGION IN WHICH IT IS ACHIEVED AND THE SUSTAINABLE ACTIONS TO MINIMIZE THEM, IN THE VISION OF AN EVENT MANAGER}

\section{ABSTRACT}

This paper aims to show the environmental impacts that a major event causes in the region in which it is carried out and the sustainable actions to minimize them, in the view of an event manager. Sustainability has been a hotly debated issue in the 21st century by large companies that are seeking to combine their activities with actions that can reduce environmental impacts on nature. Large events move the economy and modify the environment in the region where they are made, making them attractive to investors, those events that seek to reduce environmental impacts in the region and, more than that, provide sustainability improvements that are inherited for the region. Thinking about this, the researcher sought to identify the public profile of a major event, identified actions to plan an environmentally sustainable event in the opinion of an event manager and finally studied the environmental impacts that a major event provides in the region where it is held and what are the sustainable actions that can minimize them in the view of the event manager. The research was qualitative-quantitative and descriptive, based on a collection of documents and interviews conducted with a manager and the audience of major events. For this, a questionnaire was developed with open questions made to a manager of large events and a questionnaire of questions closed to the public of a big event. The results showed how environmental concern has been present within organizations and in the global market, attracting investors and modifying the behavior of consumers and economic activities, but this reality is still little perceived by the public attending events that work with sustainability.

KEYWORDS: Sustainability. Events. Planning. 


\section{INTRODUÇÃO}

Os grandes eventos, cada vez mais freqüentes no mundo contemporâneo, são importantes, pois movimentam a economia de uma determinada região, como por exemplo: as copas do mundo, os jogos olímpicos, os festivais de música, as corridas de Fórmula 1, as feiras e as convenções. De acordo com Pires (2012) o setor de eventos é o quarto colocado na pauta de exportações brasileiras, crescendo $7 \%$ ao ano, gerando três milhões de empregos diretos e indiretos. Assim se percebe a importância econômica de se realizar grandes eventos, pois estes impactam positivamente no aquecimento do turismo e na própria economia das cidades. Quando se atrai turismo desse segmento, todos os outros setores, direta ou indiretamente, são favorecidos, tais como: meios de hospedagem, transporte terrestre e aéreo, bares e restaurantes, consumo no comércio e serviços, dentre outros.

Paralelamente ao crescimento do número e tamanho dos eventos, no início deste século, há exigência de que cada vez mais se alie a sustentabilidade aos grandes eventos, esta cobrança é feita tanto por parte do público alvo quanto pelos patrocinadores. As ações para minimizar os impactos ambientais são consideradas marketing positivo, já que as empresas procuram ter seus nomes associados a ações que busquem melhorar o planeta (FERNANDES; CAETANO, 2013). Neste sentido o setor de eventos, por prestar inúmeros serviços de diversos segmentos, torna-se um multiplicador destas ações sustentáveis nas mais diversas esferas da sociedade. Essa evolução ocorreu com mais intensidade a partir do agravamento da disputa de mercado, marcada pela concorrência e pela crescente dependência das empresas em relação à opinião pública, obrigando-as a realizar eventos mais ligados à sustentabilidade. Como consequência, as empresas não podem deixar de participar ou de organizar eventos que envolvam sustentabilidade, sob pena de ficarem fora do acirrado mercado. 
De acordo com Giacaglia (2003) pode-se afirmar que o evento tem como característica principal propiciar uma ocasião extraordinária ao encontro de pessoas, com finalidade específica, qual constitui o "tema" principal do evento e justifica a sua realização. É preciso atribuir ao seu processo os princípios da sustentabilidade, desde o planejamento até o pós-evento. $\mathrm{O}$ setor de eventos aquece uma grande quantidade de atividades e fornecedores através da sua cadeia produtiva gerando impacto ambiental, social e econômico. Neste contexto destacam Ramos, Santos e Silva (2012):

os eventos não podem ser vistos como uma atividade isolada do contexto social e cultural em que estão inseridos [...] devem estar integrados ao planejamento das cidades a partir de uma política de eventos, a qual compete mobilizar os valores sociais autênticos da localidade, a fim de que estes sejam sustentáveis e permanentes (RAMOS; SANTOS; SILVA, 2012, p. 2).

Porém as questões que envolvem a sustentabilidade muitas vezes são tidas como um impasse nas organizações, isso ocorre por que as mesmas demandam planejamento e custo que podem ultrapassar interesses financeiros, mas inclui comprometimento com o aspecto socioambiental, o que reflete uma imagem positiva no negócio. A partir do momento em que as empresas introduzem o incentivo a conscientização para a sustentabilidade, dando todo e qualquer tipo de informação relacionado, é possível agir, de forma individual ou coletivamente. Assim, as empresas e as pessoas só têm a lucrar. As empresas melhoram sua imagem diante de seus clientes, podendo gerar mais lucro.

A partir disso, este artigo objetivou identificar os impactos ambientais que um grande evento musical proporciona na região em que é realizado e as quais ações sustentáveis para minimizá-los, na visão de um gestor de eventos. Para alcançar 
tal intento foram delineados os seguintes objetivos específicos: Identificar o perfil dos participantes do grande evento musical pesquisado; verificar a receptividade que a sustentabilidade nos grandes eventos têm junto a comunidade e ao público participante, na visão do gestor; e apontar os impactos ambientais que um grande evento ocasiona em uma região e as ações sustentáveis para minimizá-los, na visão do gestor;

A pesquisa se justifica frente a sustentabilidade, assunto sempre em pauta neste século, que também traz a tona responsabilidade e o valor que é dado ao meio ambiente, assim muitas empresas querem associar suas atividades e produtos às ações sustentáveis principalmente como uma estratégia de marketing e, algumas organizações percebem que, além de estratégia, também há uma redução considerável de custos.

No segmento de eventos não é diferente, pois conforme Pires (2012) as organizações deste setor vêm se mobilizando, buscando a sustentabilidade ambiental ou social e cita o aprimoramento da gestão e da sustentabilidade como os grandes desafios a serem vencidos pelo setor. Conforme Pires (2012) os eventos cada vez mais deverão ser inteligentes, verdes, interativos e geradores de novos negócios.

Grandes eventos internacionais como o Rock in Rio e o Starts With You (SWU), ao passarem uma imagem de evento ecologicamente correto, atraem patrocinadores que desejam associar sua marca a um comportamento responsável e de respeito ao planeta.

\section{FUNDAMENTAÇÃO TEÓRICA}

A seguir se apresenta conceitos de alguns autores sobre as temáticas de responsabilidade socioambiental das organizações, eventos, eventos musicais e eventos musicais sustentáveis. Estes temas estão encadeados, pois a sustentabilidade, principalmente a ambiental, é apontada como a solução para a

ReMas - Revista Metodista de Administração do Sul, v. 2, N. 2, 2017 
redução dos impactos resultante dos grandes eventos musicais cada vez mais frentes no mundo contemporâneo, colocando na berlinda o modelo organização atuais.

\section{Responsabilidade socioambiental nas organizações}

Os problemas ambientais que afetam o planeta estão cada vez mais expostos a mídia, sendo assunto discutido em diversas organizações e invadindo os lares de milhões de pessoas, criando expectativas sociais que apontam para a necessidade de superação para esta crise ecológica.

Segundo Laville (2009) o desenvolvimento sustentável remete a ideia de um crescimento que possa se manter em longo prazo, de maneira a espalhar seus efeitos benéficos sobre as futuras gerações. O objetivo é melhorar a produtividade das matérias-primas, como foi feito com o trabalho humano durante a era industrial. As condições necessárias para isso são a concepção dos produtos e o modo de fabricação de maneira a evitar o desperdício e resíduos na produção e no consumo, e também no final da vida dos produtos.

No ponto de vista de Moura (2004) a implementação de práticas ambientais corretas na empresa são sempre interessantes e necessárias, trazendo inúmeros benefícios. Dependendo do porte da organização, passa a ser necessário existir um setor específico voltado a essas atividades e que cuide dos aspectos ambientais dos produtos, serviços e processos industriais, eventualmente implantando-se um sistema de gerenciamento ambiental. De acordo com o autor dependendo dos interesses envolvidos, pode vir a ser interessante obter a certificação ambiental relativa ao cumprimento de alguma norma, com vistas à exportação ou percebendo uma exigência de clientes. Neste sentido Tachizawa (2006) expõe que: 
A transformação e a influência ecológica nos negócios se farão sentir de maneira crescente e com efeitos econômicos cada vez mais profundos. As organizações que tomarem decisões estratégicas integradas à questão ambiental e ecológica conseguirão significativas vantagens competitivas, quando não, redução de custos e incremento nos lucros a médio e longo prazos (TACHIZAWA, 2006, p.73).

Conforme o Instituto Akatu (2007) em um artigo denominado Responsabilidade Social Empresarial: o que o consumidor consciente espera das empresas, a Responsabilidade Social Empresarial é um tema central no mundo de hoje e conquista a cada ano uma maior importância no cenário nacional e global. Cada vez mais as empresas privadas movimentam recursos numa dimensão que foge às fronteiras de cada país, e em volumes também superiores aos de muitas nações. A inclusão de elementos que, de algum modo, levem fatores sociais e ambientais nas decisões empresariais é vital para que o poder das empresas seja também benéfico à sustentabilidade global.

De acordo Demajorovic (2003) o desenvolvimento sustentável não se refere especificamente a um problema limitado de adequações ecológicas de um processo social, mas a uma estratégia ou modelo múltiplo para a sociedade, que deve levar em conta tanto a viabilidade econômica como a ecológica. Completando esta ideia, Dias (2009) expõe que entre os comportamentos assumidos por esses, cada vez mais numerosos, grupos ambientalistas conscientes, esta o consumo ecologicamente sustentável. Consumir respeitando o meio ambiente é uma tendência irreversível e que crescerá de forma significativa nos próximos anos, pois tem uma relação direta com os problemas ecológicos que se avolumam. Moura (2004) afirma que:

As empresas, como produtoras dos bens e serviços, estão hoje em grande evidencia na questão ambiental. Sobretudo nos países desenvolvidos, as pressões exercidas pelas comunidades, ONGs e governos, tem forçado a uma postura pró-ativa na melhoria de seus processos pro-

REMAS - Revista Metodista de Administração do Sul, v. 2, N. 2, 2017 
dutivos, com a geração de menor quantidade de resíduos e poluentes e menor consumo de matérias-primas e energia (MOURA, 2004, p.1).

Além disso, conforme Barbieri (2007) a preocupação com a natureza é discutida no escopo da sustentabilidade, onde também há o impacto social da atividade econômica e a capacidade de sobrevivência da organização. Ou seja, conforme este autor, a otimização e a consciência do uso dos recursos na produção, pode representar ganhos econômicos, sociais e principalmente de imagem para a companhia perante a sociedade. O pensamento de Barbieri (2007) considera que:

As propostas de gestão ambiental empresarial decorrentes dessa visão devem se apoiar em três critérios de desempenho, a saber: eficiência econômica, equidade social e respeito ao meio ambiente, critérios estes que devem ser considerados simultaneamente. Espera-se que a doação dessas propostas possa contribuir para gerar renda e riqueza, os objetivos básicos das empresas: minimizar seus impactos ambientais adversos, maximizar os benefícios e tornar a sociedade mais justa (BARBIERI, 2007, p. 29).

Conforme apontam Robles Jr. e Bonelli (2010) por serem em grande parte organizações, os clientes começam a entender que a perenidade de uma organização fornecedora depende de sua capacidade para identificar e responder às demandas de todas as partes interessadas que podem efetivamente afetar a sua sobrevivência e crescimento. Por isto, tem aumentado por parte dos clientes e consumidores, ao longo de cadeia de fornecimento, as exigências acerca da demonstração da responsabilidade ocupacional, ambiental e socioeconômica ampla. Na concepção de Makower (2009):

Os problemas ambientais agora são diferentes, mais complexos e mais difíceis de ignorar e deixar de lado. Os tempos mudaram, também. As estratégias das companhias precisam refletir essas mudanças e complexidade, indo além dos slogans simples ou ações mais ecológicas ao 
acaso, para gerar algumas mudanças fundamentais na forma como os negócios são realizados (MAKOWER, 2009, p.22).

Concluindo o pensamento Lima (2005) dia que o verdadeiro conceito de desenvolvimento sustentável congrega variáveis econômicas, sociais e ecológicas. Esse tripé resume toda a estrutura que sustenta uma sociedade. A ruptura de um desses pilares pode provocar sérios danos aos demais. Assim, o desenvolvimento, de qualquer natureza, precisa conciliar e preservar essas estruturas, de forma a não comprometer suas bases e sustentação

\section{Eventos}

Segundo Matias (2011) A atividade eventos, desde suas origens até os dias atuais, passou por vários períodos da história, assumindo características e tipos que melhor representassem a época. Atualmente, abrange uma diversidade de segmentos, como os culturais, os sociais, os corporativos, os ambientais, os científicos e os desportivos, entre outros. Portanto, por reunir um grande número de pessoas dos mais diversos níveis socioeconômicos e graus de formação, o que lhe confere importância, a atividade eventos merece ser estudada e tratada de forma profissional. Rogers e Martin (2011) completam,

A indústria de eventos é um ramo de atividade recente e dinâmico que está crescendo e amadurecendo com grande rapidez. Com origens na Europa e América do Norte, e atualmente uma indústria genuinamente internacional, que é alvo de grandes investimentos, em todos os continentes. Entretanto, seu caráter de área ainda em formação implica a ausência de algumas características essenciais, já presentes em indústrias mais consolidadas, tais como uma terminologia bem definida, inteligência de mercado adequada, estruturas de treinamento e especialização apropriadas e caminhos mais claros de entrada de empresas no mercado (ROGERS; MARTIN, 2011, p.1). 
Corroborando esta ideia Allen (2003) expõe que atualmente os eventos são mais essências à cultura do que jamais foram. O tempo de lazer maior e a maneira mais cuidadosa de gastar levaram à proliferação de eventos públicos, celebrações e entretenimento. Os eventos transbordam dos jornais e telas de televisão, ocupam muito do tempo e enriquecem a vida das pessoas. Dentro desta ideia, Ferreira e Wada (2010) dizem que a organização de um evento demanda um criterioso planejamento, com profissionais qualificados, que tenham uma visão estratégica e que não sejam apenas "tarefeiros". A expansão de percepção da atividade como impulsionadora do branding empresarial e de seu portfólio, acarretando aumento de vendas e fidelização de clientes, torna-se uma importante característica que deve ser reconhecida por todos que direta ou indiretamente atuam em sua viabilização.

No ponto de vista de Melo Neto (2000) evento é um conceito de domínio amplo. Na verdade, tudo é evento. De cursos e palestras até shows, jogos e competições esportivas, exposições, festivais, festas, mostras de arte e mesmo campanhas publicitárias criativas. Encontros reunindo pessoas para discutir e debater qualquer tema se tornam verdadeiros eventos. Cidades ganham novas vidas com eventos. Turistas viajam o mundo para participar de eventos.

Tanto de forma particular quanto em público, as pessoas sentem a necessidade de marcar as ocasiões importantes da sua vida e de festejar os principais momentos. Completando esta ideia, Zobaran (2004) afirma que:

Um dos combustíveis do setor de turismo e entretenimento são os eventos, sobretudo os megaeventos. Estes trazem recursos para a cidade que os hospeda, reconhecimento e posicionamento de marca para as empresas que participam geração de renda e promoção da localidade. Alem disso, refletem os signos e hábitos culturais de uma população ou grupo social. (ZOBARAN, 2004, p.22). 
No ponto de vista de Rogers e Martin (2011) organizar um evento de sucesso depende de uma serie de fatores interligados, dentre os quais esta a eficiência de comunicação do trabalho em equipe entre o organizador e o espaço em que o evento será realizado. Corroborando com esta ideia Martin (2003) diz que cada tipo de evento tem suas diferenças e características quanto ao formato, operação, entre outros. Também o número total de participantes pode ser um desses destaques. Por suas características abrangentes, uma única feira pode facilmente receber milhares de visitantes. Por isso, esse tipo de evento é extremamente interessante para os empreendimentos hoteleiros, especialmente os que se localizam perto de grandes centros de exposição. Atentar para o calendário de eventos desses locais é fundamental para se executar um bom trabalho de vendas. Paiva e Neves (2008), afirmam que:

O evento deve ser criado considerando-se uma visão integradora que abrange outras empresas como as do turismo, a sociedade, os organizadores e os clientes ou visitantes. As organizações envolvidas com os eventos deverão criar a experiência do evento para os turistas e visitantes por meio dos benefícios a serem desenvolvidos, além de poderem criar pacotes de produtos que maximizem o aproveitamento do potencial comercial do evento (PAIVA; NEVES, 2008, p.11).

Melo Neto (2000) completa que um evento, independentemente da sua natureza, e seus propósitos, é um meio de entretenimento. O que varia, de evento para evento, são os recursos estratégicos utilizados para unir entretenimento a esportes, no caso de eventos esportivos, entretenimento-artes, no caso de eventos artísticos, entretenimento-atividades sociais, no caso de eventos sociais, entretenimento-política, no caso de eventos de mobilização políticas, e assim sucessivamente.

O planejamento é fundamental para qualquer tipo de atividade, principalmente em eventos. De forma geral, planejar 
um grande evento significa mapear todas as possíveis ações e materiais a serem utilizados de forma que se visualize todos possíveis imprevistos. Segundo Zanella (2012) com base no planejamento global e após definidas as atividades relacionadas com o evento, devera ser estruturado o cronograma de trabalho, que é o principal instrumento da fase de operacionalização do projeto e o responsável pelo controle de sua execução. A partir das afirmações dos autores, observa-se ver que os eventos trazem benefícios culturais e socioeconômicos para as regiões onde atuam, tendo uma importante atuação no desenvolvimento e na evolução. Melo Neto (2000) completa expondo que:

Eventos são a mais nova forma de alavancagem de qualquer negócio profissional nos dias de hoje. Sem eventos, não se atrai público, não se vende, não se promovem marcas e produtos, não se faz diversão para si e para os outros. Enfim, nada se faz sem eventos. Esse principio traduz a importância dos eventos como fatores de alavancagem da indústria do entretenimento, a macro indústria do desenvolvimento da humanidade (MELO NETO, 2000, p.111).

De acordo com Diniz (2011, p. 3) “o mercado da Promoção de Eventos movimenta uma fatia mercadológica promissora, a cada ano estima-se que o mesmo evento cresça em público $12,5 \%$ e de negócios em até $24,8 \%$ ", observa-se assim que este mercado é grande e promissor, devendo alinhar-se a tendência mundial da sustentabilidade.

\section{Grandes eventos musicais e seus participantes}

Conforme destaca Petitinga (2008), os grandes festivais e as celebrações públicas existem há muito tempo nas sociedades. No mundo contemporâneo estes encontros têm aumentado de tamanho e tem servido a múltiplas causas, sendo vistos como atrações turísticas, que contribuem para a economia local. Ainda segundo Petitinga (2008):

Estes eventos têm se multiplicado e atraído um público crescente em 
busca de opções de entretenimento. Seu apelo se deve, em parte, a sua natureza única composta pela junção dos seus temas e/ou atividades e do aspecto festivo, que envolve os participantes e provoca neles diversas emoções, possibilitando-os viver experiências distintas (PETITINGA, 2008, p. 14).

Adicionalmente Mello (2003) expõe que o Brasil é reconhecido como um país de intensa musicalidade, por ter dimensões continentais e ter uma população multirracial, com a contribuição de diversas etnias, tornando seus ritmos tão ricos. É deste autor um dos poucos levantamentos abrangentes sobre os eventos musicais de grande porte no país, denominados de festivais, que foram os percussores dos grandes eventos musicais deste século

Mello (2003), em um período que o autor denominou de Era dos Festivais, ocorridos entre os anos de 1965 e 1972, escreve que estes festivais tinham como características principais o fato de serem televisionados e por apresentarem uma acirrada competição. Estes festivais realizavam-se em grandes espaços como o Maracanãzinho, no Rio de Janeiro e no Teatro da Record, em São Paulo. O autor descreve o público participante destes eventos com composto por estudantes da classe média.

Batalha (2000) reconhece o Rock in Rio como o precursor dos atuais megaeventos musicais no Brasil, além de ser ainda o maior e mais importante evento de música do país. Conforme o autor, a primeira edição deste evento ocorrida entre os dias 11 e 20 de janeiro de 1985, reuniu, em uma área de 250 mil metro quadrados, denominada a cidade do rock, cerca de 1 , 38 milhão de pessoas, contando com a presença de shows de rock de artistas renomados mundialmente. $\mathrm{O}$ site do evento expõe que, além da primeira edição, em 1985, ocorreram outras no Brasil: em 1991, no estádio do Maracanã; em 2001, em Jacarepaguá onde ocorreu o Rock in Rio I; em 2011, novamente em Jacarepaguá, registrando um público de mais de 700 mil

ReMAS - Revista Metodista de Administração do Sul, v. 2, N. 2, 2017 
pessoas, abordando o tema Por Um Mundo Melhor, despertando discussões sobre sustentabilidade e projetos sociais. Sobre o tema, Petitinga (2008) esclarece que os grandes eventos musicais do país tiveram uma contribuição relevante com o Instituto Moreira Salles (IMS), que em 2007 realizou um mapeamento dos festivais de música brasileiros, reconhecendo a existência de 437 festivais de música em atividade, existentes nas diversas regiões do país.

Contrera e Moro (2007) reconhecem no país uma vários grandes eventos musicais: entre eles o Skol Beats, Coca-Cola Vibe Zone, Tim Festival, Nokia Trends, Motomix, além do já citado Rock in Rio. Podem ser computados também os grandes shows como U2 e Rolling Stones. Destes grandes evento destaca-se o SWU (Starts With You) - Começa por Você, onde segundo informações do site do SWU, neste evento tão importante quanto os shows é o Fórum Global de Sustentabilidade, com inúmeros workshops e palestras sobre sustentabilidade, com a participação de personalidades. O site do festival traz várias ações de sustentabilidade desenvolvidas, disponibiliza o relatório de sustentabilidade do evento, além de estimular os visitantes a adotarem atitudes socioambientalmente responsáveis.

Outro grande evento musical com ações sustentáveis é o Lollapalooza, de acordo com informações contidas no site do evento o nome Lollapalooza significa uma coisa, pessoa ou evento extraordinário ou incomum. Trata-se de um festival de música anual abrangendo diversos gêneros musicais, como rock alternativo, heavy metal, punk rock, bandas de hip hop e performances de comédia e danças, além de estandes de artesanato. $\mathrm{O}$ evento também dá espaço para grupos políticos e sem fins lucrativos.

Embora sejam abundantes as discussões de cunho social dos grandes eventos musicais ocorridos no Brasil, não foram encontrados estudos traçando o perfil dos frequentadores 
destes eventos. Porém, Portugal conta com um estudo com esta abordagem. Trata-se de uma pesquisa realizada em 2014 para o Talkfest, um fórum sobre os festivais de música português. A pesquisa, realizada através da internet, reuniu 426 pesquisados, entre setembro e dezembro de 2013. Os dados obtidos que têm interesse para presente pesquisa, encontram-se sintetizados na Figura 1.

Figura 1 - Resultados parciais obtidos pela pesquisa Talkfest

FAIXA ETÁRIA

[17 - 20] 30,62\%

[2] - 24] 26,32\%

[25 - 30] $23,44 \%$

[31 - 40] $17,22 \%$

$[41-65] 2,40 \%$

OCUPAÇÃO

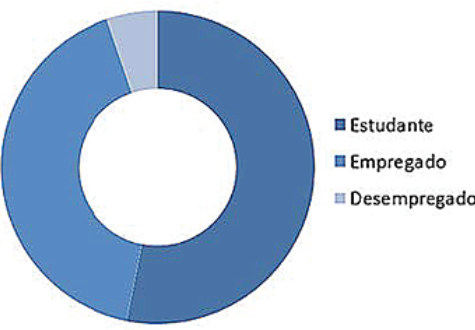

ESCOLARIDADE

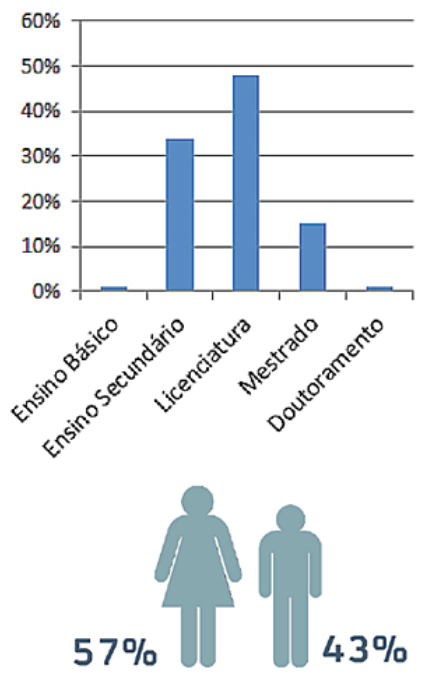

Fonte: Talkfest, 2014, modificado pelo autor

A pesquisa ainda conclui que o público que frequenta os grandes eventos musicais é exigente "e conhecedor deste tipo de eventos, fazendo comparações e análises para tomadas de decisões sobre festivais a que ir a cada ano, pois muitos são semelhantes entre si, em diferentes padrões" (TALKFEST, 2014, paginação irregular). 


\section{Eventos sustentáveis}

Conforme Diniz (2011), em uma pesquisa realizada pelo Instituto Akatu no ano de 2010, as estimativas apontam que são realizados cerca de 330 mil eventos por ano no país, capazes de atrair quase 80 milhões de participantes. A região sudeste concentra a maior parte dos eventos, promovendo quase 170 mil a cada ano, cerca de $52 \%$ do total, seguida pela região sul com 63 mil eventos anuais (19\% do total). Tudo isso é muito bom para a economia nacional. No entanto, essas realizações costumam deixar uma conta ambiental elevada. Os impactos acontecem principalmente devido ao excesso de consumo de energia e da grande quantidade de lixo produzidos ao final de cada produção. Preocupados com essas questões, promotores de eventos e empresas que investem no setor estão buscam alternativas para minimizar esses problemas. Dentro deste pensamento Voltolini (2011) afirma que:

A sustentabilidade, longe de construir uma abstração, aparece como desafio ao comando das organizações. A necessidade de mudanças endógenas, o empreendedorismo social, a questão da cidadania solidária e outros temas instigantes fazem parte dessa agenda para a sustentabilidade. E, para responder ao desafio, exige-se uma liderança que ultrapasse o potencial dos indivíduos, uma "liderança em rede" (VOLTLINI, 2011, p.7).

Focando a sustentabilidade em eventos a International Organization for Standardization (ISO ou Organização Internacional para a Normatização) aprovou em 2012 a norma ISO 20121:2012, denominada de Sistemas de gestão para a sustentabilidade de eventos - Requisitos com orientações de uso. Esta norma foi criada para garantir que eventos de todos os portes deixem um legado positivo terminada a sua realização.

De acordo com informações do site da Associação Brasileira de Normas Técnicas (ABNT), representante no Brasil 
da ISO a norma ISO 20121:2012 apresenta uma abordagem de sistema de gestão, muito semelhante às normas ISO 9000 (gestão da qualidade) e a ISO 14000 (gestão ambiental), igualmente certificável. Para alcançar a ISO 20121, uma organização precisa demonstrar que inclui em seu sistema de gestão todas as questões-chave: financeiras, econômica, sociais e ambientais relevantes para as suas operações. A Figura 3 expõe o modelo de sistema de gestão adotado pela ISO 20121:2012.

Com relação aos eventos sustentáveis Matias (2011) exemplifica que uma das principais iniciativas neste sentido foi tomada pela prefeitura de São Paulo, por meio da São Paulo Turismo S/A (SPTuris) que, no Carnaval de 2007, implantou o programa de neutralização dos impactos ambientais. Esse projeto foi realizado por uma empresa especializada que chegou ao cálculo aproximado de 700 toneladas de gás carbônico emitidos na atmosfera durante os quatro dias de desfile. Para a neutralização dessa emissão foram plantadas 1.200 árvores pela ONG SOS Mata Atlântica, por meio do Programa Florestas do Futuro.

Outro evento de destaque é o Rock in Rio, onde todas as emissões contabilizadas durante a montagem, desmontagem, shows e intervalos foram neutralizados por meio de co-financiamento de projetos de sequestro de carbono e estudo de tecnologias para redução das emissões, mais de 40 mil árvores foram plantadas depois das edições em Lisboa e em Madri; ambas no anos de 2010 (MATIAS, 2011). Complementando este pensamento Arantes, Zanin e Fontes (2008) expõem que:

O tema sustentabilidade em eventos vem ganhando espaço na mídia como forte aliado a responsabilidade ambiental empresarial, de forma que a organização de um evento mais sustentável se apresenta hoje também como um "importante mercado" atraindo diferentes grupos. Embora essa possa ser uma oportunidade para difundir melhores praticas, se a opção por um evento mais sustentável for motivada 


\section{REMAS}

REVISTA METODISTA DE ADMINISTRAÇÃO DO SUL

Figura 2 - Modelo de sistema de gestão adotado pela ISO 20121:2012

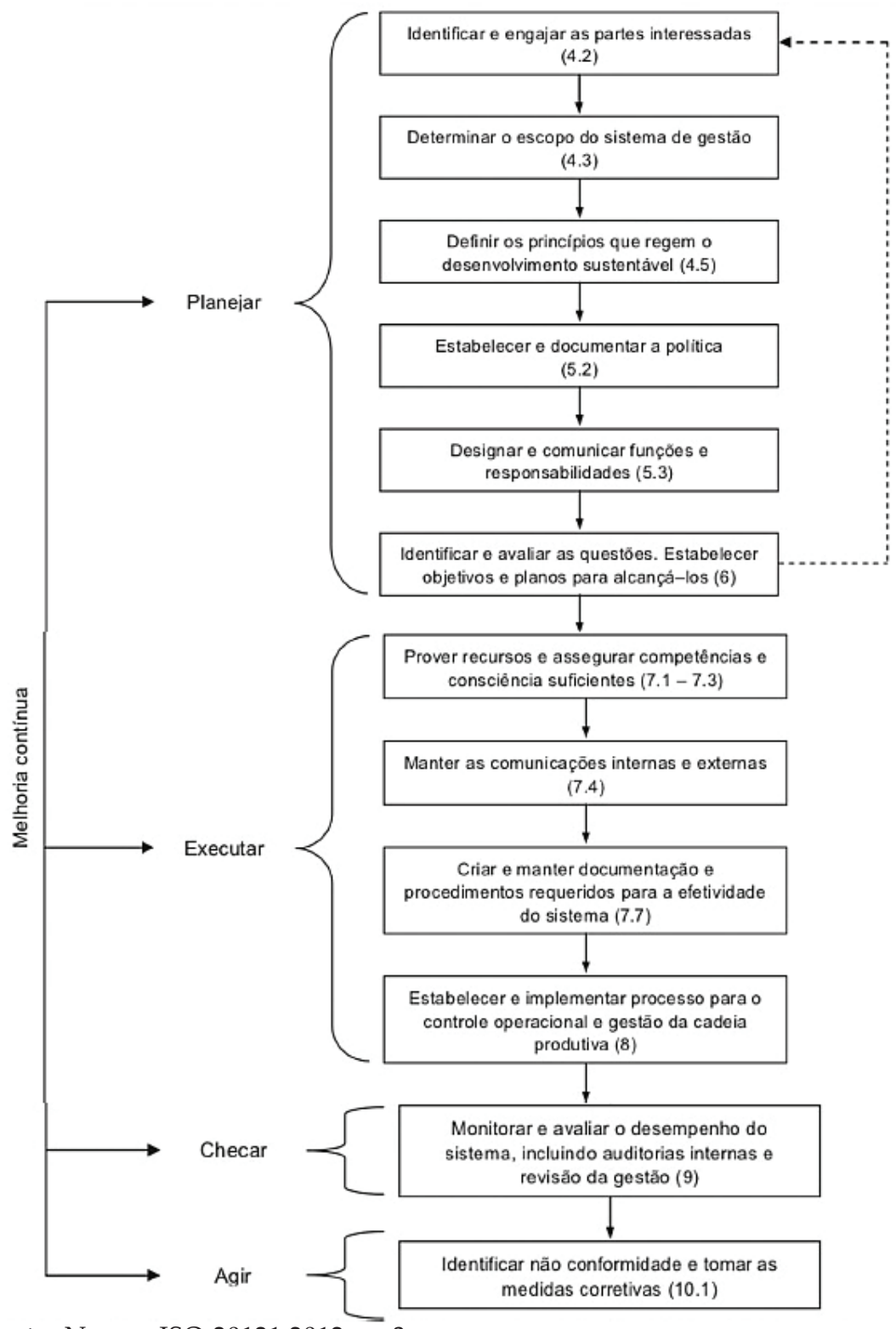

Fonte: Norma ISO 20121:2012, p. 3 
especialmente pela oportunidade de negocio, prestigio, promoção e credibilidade, corre-se de a ambição e o egoísmo prevalecerem sobre outros valores que permeiam a sustentabilidade, como a simplicidade, a solidariedade e a ética (ARANTES; ZANIN; FONTES, 2008, p.)

Conforme a pesquisa do Instituto Akatu denominada "Como e por que os brasileiros praticam o consumo consciente?" (BELINKY et a., 2006) este tipo de consumo pressupõe, além do comportamento individual, a mobilização e a influência sobre outras pessoas, de modo a estimular o crescimento das atitudes que possam proteger a sustentabilidade da vida no planeta.

Neste sentido, destaca-se a iniciativa pioneira no Brasil da publicação do primeiro relatório de sustentabilidade de eventos utilizando a metodologia do Global Reporting Initiative (GRI) do megaevento de música SWU (Figura 3). O GRI é uma organização não-governamental internacional, com sede em Amsterdã, que difunde as diretrizes para a construção de relatórios de sustentabilidade no mundo todo. 
REMAS

REVISTA METODISTA DE ADMINISTRAÇÃO DO SUL

Figura 3 - Capa do relatório de sustentabilidade do SWU que utiliza o modelo GRI

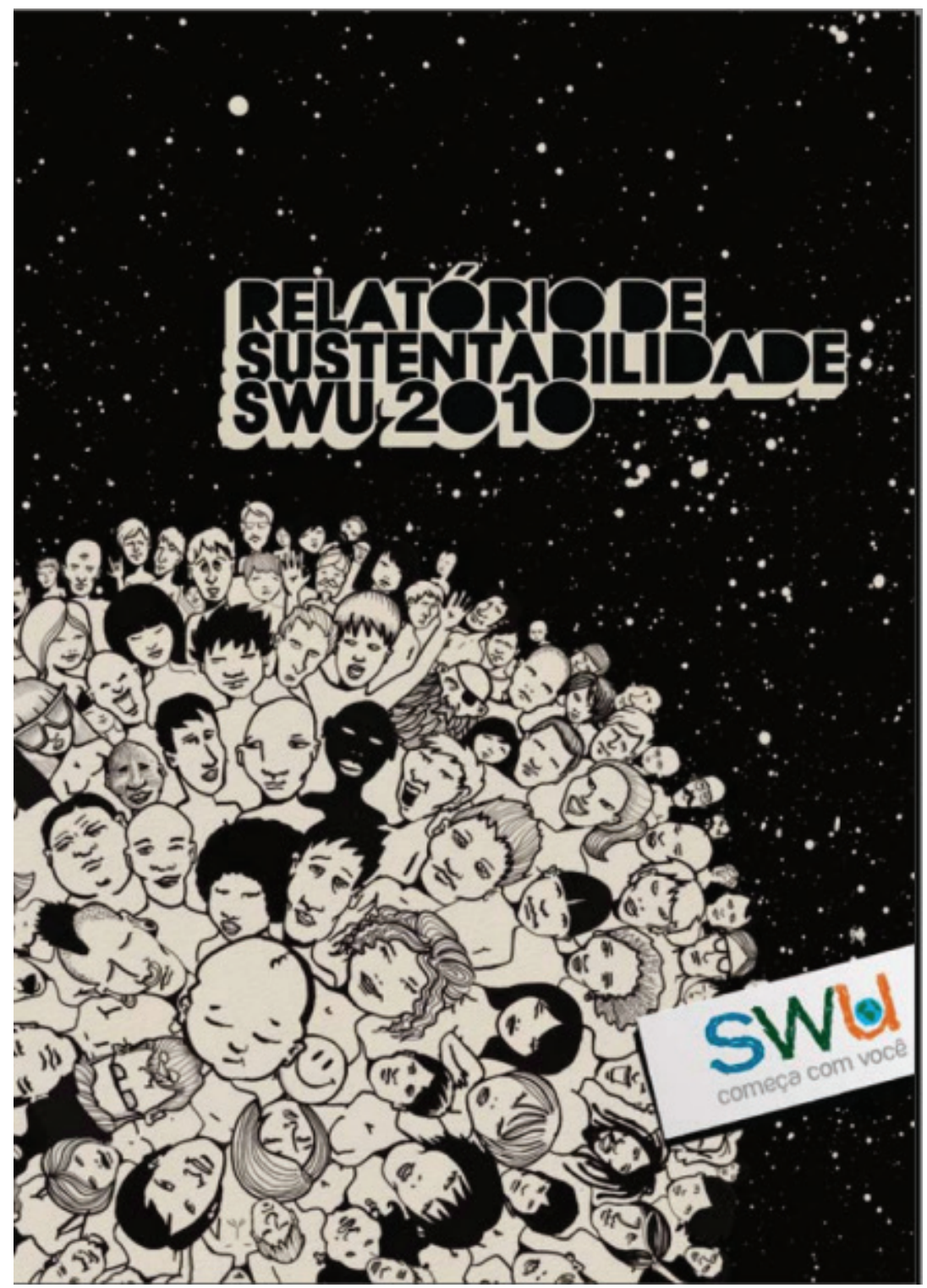

Fonte: site do SWU, 2013

162 Remas • Revista Metodista de Administração do Sul, v. 2, n. 2, 2017 
Com relação aos eventos sustentáveis o próprio relatório do GRI estabelece cinco passos para a sua metodologia, que foram traduzidas pelo pesquisador, já que o relatório ainda não tem versão em português, e sintetizado no Quadro 1 (GRI, 2012).

Quadro 1 - Modelo de sistema de gestão adotado pela ISO 20121:2012

\begin{tabular}{|c|l|}
\hline 1 & $\begin{array}{l}\text { Preparação: criação de um plano de ação para a elaboração } \\
\text { do relatório, incluindo a construção de cronograma, a } \\
\text { definição de uma equipe e a organização das principais } \\
\text { fases da elaboração do relatório. }\end{array}$ \\
\hline 2 & $\begin{array}{l}\text { Engajamento: identificação de partes interessadas, } \\
\text { priorização e estabelecimento de um método de } \\
\text { comunicação e diálogo que irá contribuir para a elaboração } \\
\text { do relatório. }\end{array}$ \\
\hline 3 & $\begin{array}{l}\text { Definição: seleção de temas que estarão no relatório e } \\
\text { escolha de indicadores de desempenho. }\end{array}$ \\
\hline $\mathbf{4}$ & $\begin{array}{l}\text { Monitoramento: verificar os processos e medir o } \\
\text { desempenho da organização através dos indicadores. Para } \\
\text { garantir a qualidade das informações é fundamental que a } \\
\text { coleta e o registro de informações sejam precisos. }\end{array}$ \\
\hline 5 & $\begin{array}{l}\text { Comunicação: definir forma de redação do relatório e } \\
\text { mecanismos de divulgação. }\end{array}$ \\
\hline
\end{tabular}

Fonte: GRI (2012).

No Rio Grande do Sul também existem iniciativas inovadoras, como o ocorrido, no ano de 2011, durante o evento Planeta Atlântida no Rio Grande do Sul e Santa Catarina, marca de cerveja Nova Schin realizou uma ação de sustentabilidade que tinha como objetivo arrecadar as latas de bebidas que eram consumidas pelo público durante o evento. A ação acontecia no Espaço Reciclão, onde os participantes arremessavam latinhas em cesto de jogo de basquete, mesclando diversão com 
consciência ambiental (Figura 4). Entre as duas edições do evento, foram recolhidas mais de quatro toneladas de latinhas para reciclagem.

Figura 5 - Fotografia do Espaço Reciclão

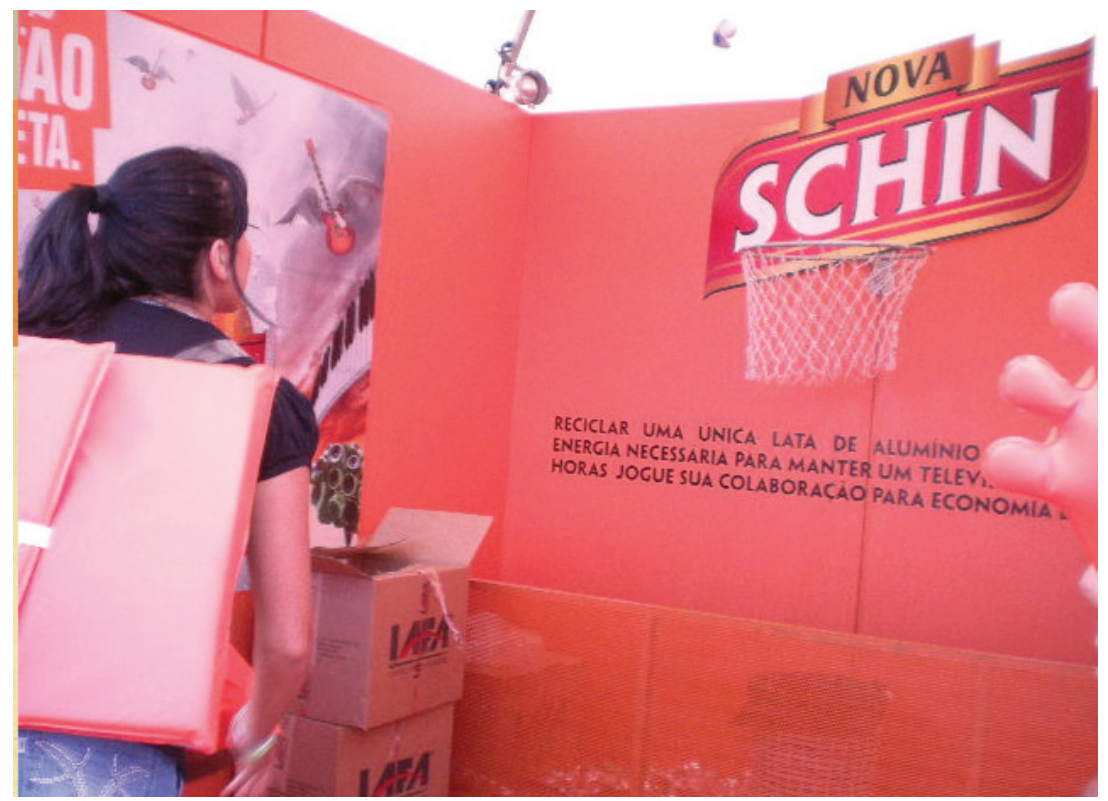

Fonte: Jornal Zero Hora, 2013

De forma semelhante, na edição de 2013 do Rock in Rio a marca de cerveja Heineken comemorou a marca de 460 mil litros de chope comercializados para os adultos, servidos em aproximadamente 1.150 milhões de copos. Para incentivar o consumo responsável da cerveja e o engajamento com o meio ambiente, desenvolveu a ação Rock $\mathcal{E}$ Recycle que estimulou o público a trocar o material reciclável por brindes. Esta ação resultou em um total de mais de $17 \%$ de todos os copos do evento sendo reciclados com o apoio de mais de 20 mil participantes. As 200 mil embalagens foram substituídas por 20 
mil brindes, incluindo bonés, broches, porta-copos, camisetas e copos de água.

\section{METODOLOGIA}

Quanto aos seus objetivos, o presente artigo caracteriza-se como uma pesquisa descritiva que, segundo Gil (2010), tem como objetivo a descrição das características de determinada população. Gil (2010, p.28) relata ainda, que "algumas pesquisas descritivas vão além da simples identificação da existência das relações entre variáveis, e pretendem determinar a natureza dessa relação". A pesquisa traz uma abordagem qualitativa e quantitativa, e se baseia em um procedimento de levantamento de campo.

A pesquisa ficou delimitada a um grande evento musical, aqui denominado de Evento $X$, realizado por uma empresa da cidade de Porto Alegre, com reconhecida atuação em grandes eventos no sul do país, realizado no verão de 2014. O sujeito desta pesquisa compreende um gestor da empresa de eventos da cidade de Porto Alegre, a qual busca utilizar métodos sustentáveis para realização do seu trabalho. Já a população pesquisada caracteriza-se por uma parcela do público participante do evento organizado pela empresa pesquisada.

$\mathrm{Na}$ pesquisa quantitativa a população pesquisada se caracterizou por todos frequentadores do Evento $X$, no dia oito de fevereiro de 2014, no intervalo entre às 08h:00nin e às 03h:00min, atendendo as condicionantes da pesquisa impostas pela empresa, que foram: um dia de pesquisa em um intervalo de tempo preestabelecido, não superior a sete horas de duração. Com estas condicionantes escolheu-se o último dia do evento, onde a estimativa foi de 47.500 participantes. A partir destas informações e restrições foi aplicado o cálculo amostral com um nível de confiança ficou inferior a $6 \%$ e o nível de confiança é superior a $90 \%$, onde se obteve uma amostra

ReMas - Revista Metodista de Administração do Sul, v. 2, N. 2, 2017 
de 330 participantes. Estabelecida a amostra o pesquisador, realizou a pesquisa através de questionários auto aplicáveis, com onze perguntas fechadas, de escolha simples, permitindo uma rápida resposta, abordando os pesquisados aleatoriamente junto as áreas de grande circulação, na entrada do evento e próximo as áreas de alimentação. Este grupo foi definido como a amostra, atende ao que preconiza Vergara (2009, p. 50) onde a "população amostral ou amostra é uma parte do universo (população) escolhida segundo algum critério de representatividade".

Na pesquisa qualitativa realizou-se uma entrevista com a Gestora de Entretenimento da empresa de eventos, a partir de um roteiro estruturado, composto de 20 perguntas abertas e fechadas. Sobre a entrevista Pádua (2004) explica que:

As entrevistas constituem uma técnica alternativa para se coletar dados não documentados, sobre um determinado tema. Deve-se levar em consideração que a entrevista tem suas limitações; dependendo da técnica a ser adotada, os entrevistados podem não dar as informações de modo preciso ou o entrevistador pode avaliar/julgar/interpretar de forma distorcida as informações obtidas (PÁDUA, 2004, p.70).

A terceira e última etapa da pesquisa consistiu na observação assistemática, que conforme Reis e Campos (2010) é uma técnica que tem variações segundo o grau de participação do pesquisador no campo, para tanto o pesquisador elaborou um roteiro de observação de campo.

Para a interpretação dos dados obtidos foi utilizada a estatística descritiva, para os dados quantitativos, combinada a uma análise interpretativa, para os dados qualitativos, que de acordo com Marconi e Lakatos (2010) é aquela que pretende:

fazer uma crítica, do ponto de vista da coerência interna e validade dos argumentos empregados no texto e da profundidade e originalidade dada à análise do problema, realizar uma apreciação pessoal e mesmo 
emissão de juízo sobre as ideias expostas e defendidas (MARCONI; LAKATOS, 2010, p. 32).

Desta forma, buscou-se não apenas coletar, tabular e descrever os dados, mas especialmente relacioná-los às teorias existentes, buscando-se uma relação coerente entre os dados analisados.

\section{RESULTADOS E DISCUSSÃO DA PESQUISA}

O evento musical abordado na pesquisa surgiu no final da década de 1990, é considerado um dos maiores festivais de música do Brasil. O Evento $\mathrm{X}$ une música e entretenimento, trazendo diversas ações de interação entre o público, as bandas e os patrocinadores. $\mathrm{O}$ evento possui ambientes temáticos com áreas especiais e exclusivas para os patrocinadores poderem interagir com o público, trazendo brincadeiras, jogos, ações de merchandising e experimentação e lançamento de produtos. $\mathrm{O}$ Evento X é realizado em duas edições em dois Estados, que somam um público aproximado de 150 mil pessoas. No Rio Grande do Sul, ocorre no litoral gaúcho. Em Santa Catarina a cidade de Florianópolis é a sede do evento.

Para estabelecer o perfil dos participantes do Evento X se buscou definir a faixa etária dos mesmos, com relação à idade se observou que mais da metade dos participantes do Evento $X$, somando $53 \%$, têm entre 15 e 20 anos; $19 \%$ têm idade entre 20 e 25 anos; $7 \%$ têm entre 26 e 30 anos; $11 \%$ estão na faixa entre os 31 e 35 anos; $5 \%$ têm entre 36 e 40 anos; $2 \%$ pertencem ao intervalo entre 41 e 45 anos; e menos de 3\% têm idade superior a 46 anos (Gráfico 1). 
Gráfico 1 - Idade dos pesquisados

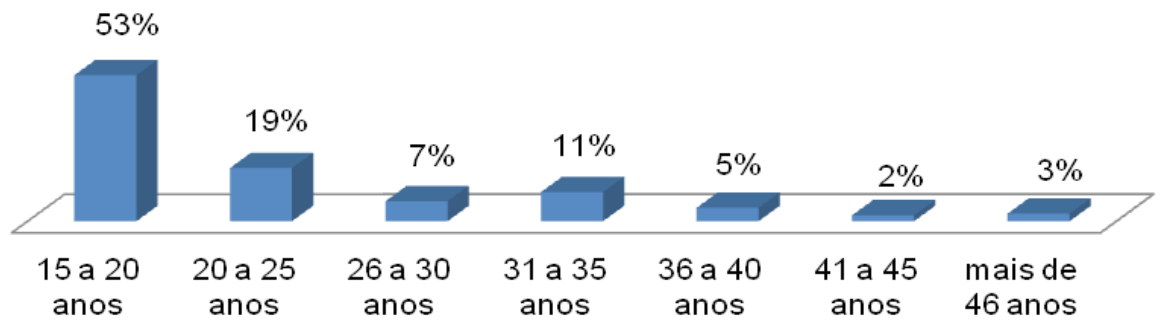

Fonte: Dados da pesquisa

Estes dados vem ao encontro dos obtidos pelo Talkfest (2014) que indica uma faixa etária entre 17 a 20 anos com predominante neste evento, somando $30,62 \%$; seguida da faixa entre 21 a 24 anos (26,32\%); 25 a 30 anos (23,44\%); 31 a 40 anos $(17,22 \%)$; finalizando com os participantes com idade entre 41 a 65 anos, que somam 2,40\% dos participantes de grandes eventos musicais.

Com relação ao gênero dos participantes, a pesquisa mostrou que a maioria é feminina, um total de 219 mulheres, perfazendo $65 \%$ dos entrevistados; frente a 112 do gênero masculino, somando $34 \%$ de homens. Estes dados são corroborados pelos dados do Talkfest (2014) onde o público feminino também é a maioria, perfazendo $57 \%$; o público masculino soma $43 \%$.

No que se refere à escolaridade dos entrevistados, $49 \%$ dos pesquisados compõem-se de estudantes com ensino médio completo, somando 162 entrevistados; $28 \%$ possuem o ensino superior incompleto, com 93 entrevistados; 15\% completaram o ensino superior, 49 pessoas; $7 \%$, cursam o ensino médio, num total de 23 pessoas; e apenas $1 \%$, três pessoas, é pós-graduado (Gráfico 2). 
Gráfico 2 - Escolaridade dos pesquisados

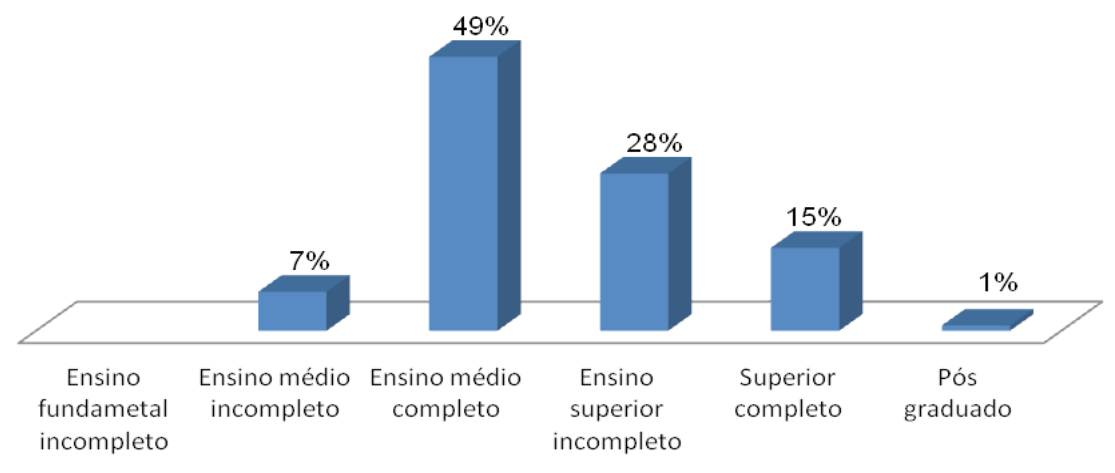

Fonte: Dados da pesquisa

Neste quesito os dados do Talkfest (2014) diferem dos obtidos na presente pesquisa, pois em Portugal a maioria dos frequentadores de festivais musicais cursam ou têm o ensino superior completo, somando próximo a 50\%. Seguem os estudantes que cursam o ensino secundário, perfazendo pouco mais de $30 \%$ e os pós graduados, somando cerca de $15 \%$. A diferença observada certamente deve-se ao maior nível de escolaridade português.

Quanto à atividade dos participantes do Evento $\mathrm{X}$, verificou-se que a maioria, 52\%, somando 171 pessoas é de estudante; $8 \%$, perfazendo 28 pesquisados, realizam algum tipo de estágio; 22 dos entrevistados, representados por 7\% são auxiliares administrativos; os professores somam $4 \%$ dos entrevistados (12 pessoas); os comerciantes 3\%, com 9 entrevistados; os advogados, dentistas e secretárias perfazem cada um $2 \%$ do total de entrevistados, com oito representantes cada categoria; as demais categorias perfazem $30 \%$, somando 75 pesquisados; referem-se a profissões variadas como: funcionários públicos, gerentes, empresários, autônomos, bancários, engenheiros, músicos entre outros (Gráfico 3). A pesquisa apontou que 
existem $2 \%$ dos pesquisados, somando quatro pessoas que estão desempregadas.

Gráfico 3 - Profissão dos pesquisados

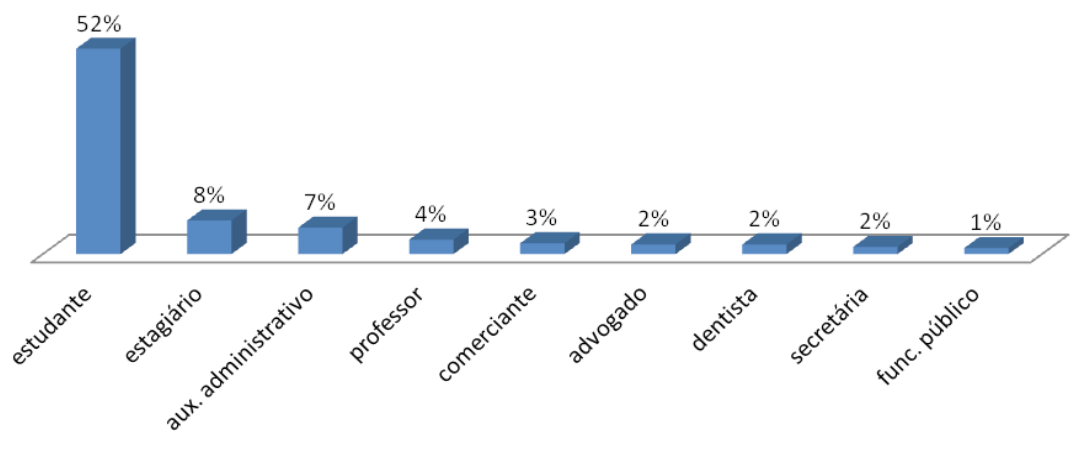

Fonte: Dados da pesquisa

A pesquisa do Talkfest (2014), a semelhança da presente pesquisa, aponta que a maioria do público presente nos grandes festivais musicais é de estudantes, somando cerca de $55 \%$ dos frequentadores; cerca de $40 \%$ possui um emprego, embora este não tenha sido especificado; e aproximadamente $5 \%$ do público está desempregado.

O baixo índice de desemprego, de $2 \%$, apontado na presente pesquisa certamente reflete o preço dos ingressos, onde os desempregados por não terem renda, não podem ou não querem arcar com o valor do ingresso de, no mínimo, $\mathrm{R} \$$ 130,00. A taxa de desemprego apontada pela presente pesquisa igualmente difere da taxa apresentada para o mês de março de 2014, pelo Instituto Brasileiro de Geografia e Estatística, na Pesquisa Mensal de Emprego (PME) (IBGE, 2014), onde este índice alcançou $5 \%$.

Referente à naturalidade dos pesquisados, identificou-se que a maioria, 39\%, somando 129 pessoas, reside na cidade 
de Porto Alegre; $8 \%$, em um total de 25 pessoas, moram em Canoas; $6 \%$, representando 22 pessoas, moram em Novo Hamburgo; 5\%, num total de 17 pessoas, residem em Santa Maria; $4 \%$, no total de 15 pessoas, moram em Lajeado; 11 pessoas, perfazendo e 3\%, residem em Viamão; os demais 129 entrevistados residem nas cidades de Caxias do Sul, Torres, Portão, Teutônia, Três Cachoeiras, Rio Pardo, Esteio, Rio Grande, Pelotas, e Passo Fundo, além de outras 33 cidades do Rio Grande do Sul. Apenas 1\%, representado por três pessoas da cidade de Sombrio e duas da cidade de Içara, no Estado de Santa Catarina (Gráfico 4).

Gráfico 4 - Naturalidade dos pesquisados

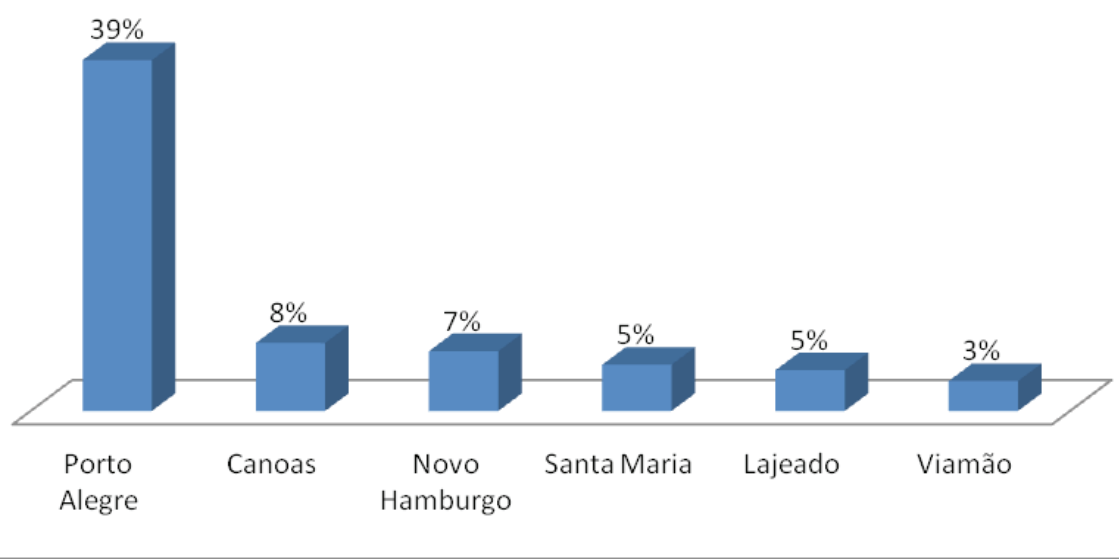

Fonte: Dados da pesquisa, 2014

As próximas quatro questões buscam verificar o conhecimento que os pesquisados tem sobre a sustentabilidade e eventos sustentáveis, assim referente à questão de conhecimento sobre o que é sustentabilidade, $92 \%$ dos entrevistados responderam que sabem o que é sustentabilidade, somando 305 respostas afirmativas; contra apenas $8 \%$, num total de 25 respostas de pesquisados que desconhecem o assunto.

ReMas - Revista Metodista de Administração do Sul, v. 2, N. 2, 2017 
Neste ponto o autor buscou referências para apresentar um contraponto com o resultado obtido, entretanto elas são escassas, porém Feitosa (2011), em uma pesquisa com 441 alunos da Faculdade de Administração da Universidade de São Paulo (FEA-USP), revelou que 55\% dos alunos da FEA-USP reconhecem o conceito de sustentabilidade clássico, proveniente do Relatório Bruntland. Frente a este fato, pode se inferir que $92 \%$ dos pesquisados afirmarem que sabem o que é a sustentabilidade parece ser exagerada, sendo possível que o índice represente que os pesquisados já tenham ouvido falar com frequência na sustentabilidade.

Quando questionados sobre a participação em eventos focados na sustentabilidade, a maioria dos pesquisados, somando $61 \%$ dos entrevistados, representados por um total de 200 pessoas, afirmaram não ter frequentando evento focado em sustentabilidade; e 39\% dos pesquisados, em um total de 130 pessoas responderam já ter frequentado um grande evento que trabalhasse com a sustentabilidade. Nesta questão foi solicitado aos pesquisados que apontassem os eventos com foco sustentável do qual participaram, sendo nomeados os seguintes eventos: Planeta Atlântida; Rosário Sustentável; Rock in Rio; UNISINOS Love Green; além de eventos diversos em escolas, faculdades, empresas (sendo citadas a Gerdau e Souza Cruz) e congressos.

De forma a complementar a questão anterior foi questionada a participação dos pesquisados em ações de sustentabilidade. Nesta questão, a maioria, representada por 295 entrevistados, perfazendo $89 \%$, diz nunca ter participado de uma ação de sustentabilidade; contra 35 entrevistados, representando o equivalente a $11 \%$ do total, que disse já ter participado de alguma ação sustentável. De acordo com os dados do $5^{\underline{o}}$ Dossiê Universo Jovem, produzido pela MTV Brasil, que é uma pesquisa que a emissora prepara a cada três anos para conhecer os valores, comportamentos e atitudes dos jovens em relação a assuntos que lhes são relevantes. A pesquisa ouviu 
2.000 jovens, entre 12 a 30 anos, pertencentes as classes $\mathrm{A}, \mathrm{B}$ e C, nas capitais São Paulo, Rio de Janeiro, Belo Horizonte, Brasília, Salvador, Recife, Porto Alegre e no Interior de São Paulo, em julho de 2010. Esta pesquisa mostra que o percentual de jovens ambientalmente engajados está em torno de $17 \%$. Neste cenário observa-se que as respostas dos pesquisados se aproxima da obtida pela pesquisa da MTV, já que alcança $11 \%$ de jovens com alguma participação em evento sustentável.

O questionário se encerra com a apresentação de quatro grandes festivais nacionais: Planeta Atlântida, SWU, Rock in Rio e o Lollapalooza; e um internacional, o Coachella, que desenvolvem, em maior ou menor grau, alguma ação de sustentabilidade, sendo que os pesquisados são questionados sobre seu conhecimento destes eventos. Nesta questão, se obteve um resultado de $45 \%$, num total de 295 respostas, afirmando conhecer o evento Planeta Atlântida; 26\% dos pesquisados, com 190 respondentes, disseram conhecer o Rock in Rio; 82 respondentes, perfazendo $13 \%$, conhecem o SWU; $7 \%$ dos pesquisados, com 48 respostas, conhecem o Lollapaloozza; e 7\% (38 repostas) apontaram o Coachella (Gráfico 5).

Gráfico 5 - Eventos sustentáveis que os pesquisados conhecem

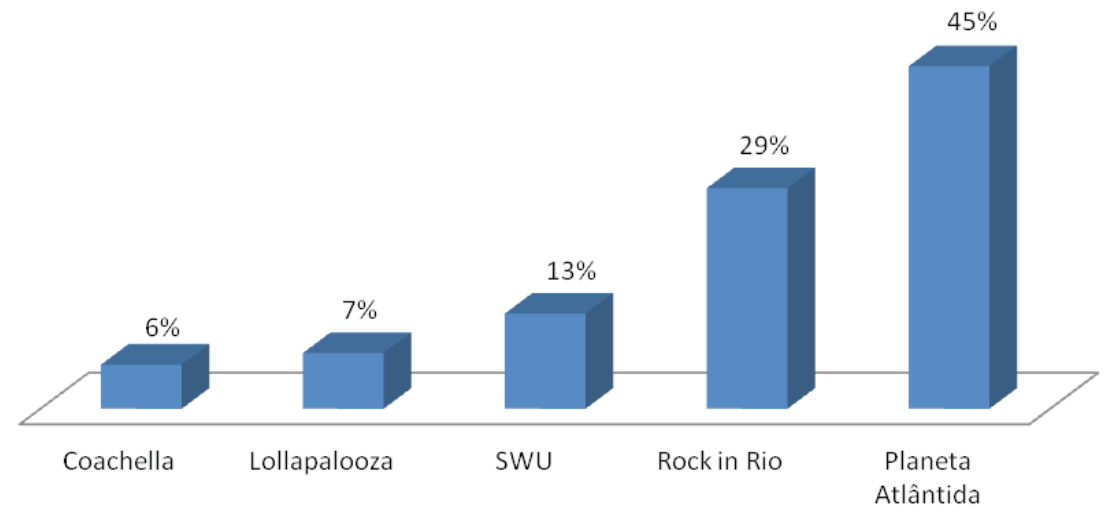

Fonte: o autor, 2014

ReMAS • Revista Metodista de Administração do Sul, v. 2, N. 2, 2017 
Finalizado o questionário foi possível estabelecer que o perfil do participante do grande evento pesquisado, onde os dados apurados mostram que o mesmo é do sexo feminino, somando $65 \%$ dos entrevistados, com idade entre 15 a 20 anos, somando 53\% dos entrevistados, residente em Porto Alegre (39\%), com o ensino médio completo (49\%) e é predominantemente estudante (52\%). Afirma conhecer o que é a sustentabilidade $(92 \%)$, mas não participou de nenhum evento $(61 \%)$ ou ação $(89 \%)$ com este alinhamento.

Buscando verificar a receptividade que a sustentabilidade ambiental nos grandes eventos têm junto a comunidade e ao público participante, na visão do gestor deste eventos, foram elaboradas sete questões à Gestora de Entretenimento do evento pesquisado, onde inicialmente foi questionado à Entrevistada qual sua opinião sobre a importância para uma cidade ou país sediar grandes eventos alinhados ao foco na sustentabilidade, ao que a mesma respondeu que considera isto muito importante, já que a sociedade de uma forma geral está cada vez mais consciente sobre o papel da sustentabilidade ambiental. Conforme destacou a Entrevistada (2014):

sempre no final do evento nós fazemos o recolhimento e a separação do lixo orgânico, como restos de comida; e do lixo seco, como latas, copos descartáveis e garrafas plásticas e convidamos uma ONG para receber este material para poder trabalhar a reciclagem. Todos estes cuidados nós temos não só no Evento $X$, mas em outros eventos que realizamos (ENTREVISTADA, 2014).

Com relação ao setor de eventos Matias (2011) destaca que a preocupação com a sustentabilidade atingiu os mais diversos setores, inclusive o de eventos, desencadeando a necessidade de ações efetivas que minimizem os impactos do setor. Assim este conceito tornou-se uma necessidade e também um diferencial, interferindo diretamente na concorrência do mercado ou até mesmo na sobrevivência de diversas empresas. 
A seguir foi questionado à Entrevistada quais as vantagens que uma região tem ao receber um grande evento sustentável, ao que a mesma expôs que:

Acho que não é um beneficio direto, é um beneficio que se tu tem essa conscientização com o meio ambiente, com a natureza, não depende de um show, acho que faz parte da cidadania de cada um de nós, é a preservação deste ambiente (ENTREVISTADA, 2014).

A Entrevistada ainda destacou que o Evento $\mathrm{X}$ ocorre há 20 anos, sempre no mesmo local, onde foram realizadas diversas melhorias pela empresa realizadora do evento, como destaca a Entrevistada (2014) sobre estes cuidados:

cuidamos não só na natureza mas dando estruturas melhores naquele espaço, e é um local que a gente procura sempre preservar, pois é onde nós recebemos o público. Se não tivéssemos esse cuidado com o local, o cuidado com o solo, com a vegetação, talvez não conseguíssemos realizar o evento sempre no mesmo local (ENTREVISTADA, 2014).

Neste sentido Matias (2011) destaca que a mobilização da população em torno dos impactos ambientais causados pela ação humana vem tomando grande dimensão; chegou ao setor de eventos e passou a ser uma aliada que pode agregar valor ao evento, unindo responsabilidade social e sustentabilidade. Laville (2009) complementa que oferecer serviços e produtos melhores, que contribuem para uma melhor qualidade de vida e incentivem novos hábitos educam e sensibilizam a sociedade como um todo, incentivando escolhas mais conscientes por parte dos consumidores.

Referente aos indicadores que a Entrevistada considera mais importante em um grande evento que trabalhe com sustentabilidade foi respondido que todos os indicadores são importantes, e destacou que todos os eventos em que ela faz parte da gestão, trabalham com responsabilidade ambiental, 
fazendo com que todo o descarte de resíduos tenham uma destinação correta, além da preocupação com a neutralização do carbono.

A próxima pergunta abordou as vantagens que uma região pode obter recebendo um grande evento sustentável. Neste aspecto, na visão da Entrevistada, o beneficio não é direto, ressaltando que a conscientização com o meio ambiente ou com a natureza, não depende de um show, esta consciência faz parte da cidadania de cada um, organizadores, patrocinadores, público e fornecedores. A Entrevistada ainda destacou que o Evento $\mathrm{X}$ existe há 20 anos, sempre no mesmo local, em um clube no litoral gaúcho, onde já foram realizadas diversas melhorias, tanto com relação a infraestrutura como ambientais, pois é onde se recebe o público e sem este cuidado com o local, com o solo, com a vegetação, não poderia ser realizado por tanto tempo no mesmo local. Com mesmo pensamento, Matias (2011) refere que:

a preocupação com o futuro do planeta e, consequentemente, com as gerações futuras, está demonstrada pelo conceito do desenvolvimento sustentável, que nada mais é que satisfazer as necessidades do presente, sem comprometer a capacidade das gerações futuras de suprir suas próprias necessidades. Essa definição surgiu na Comissão Mundial sobre o Meio Ambiente e Desenvolvimento, criada pela Organização das Nações Unidas (ONU) para discutir e propor meios de harmonizar dois objetivos: o desenvolvimento econômico e a conservação ambiental (MATIAS, 2011, p.219).

Voltolini (2011) também salienta que qualquer organização que pretende ser sustentável deve extrapolar a visão limitada de si e criar modelos capazes de atender às demandas atuais que incluem os contextos ambiental e social.

Na questão sobre o preparo do Brasil e das empresas brasileiras em geral para desenvolver eventos sustentáveis, a Entrevistada entende que as empresas estão preparadas, 
porém o público não está. Na sua opinião a questão da sustentabilidade não pode ser imposta, pois as pessoas vão a um evento para se divertir e aproveitar e se forem criadas regras muito rígidas, as pessoas se sentem reféns das regras e não conseguem aproveitar o evento do jeito que gostariam.

A entrevistada citou como exemplo do para o despreparo do público o festival SWU, que mescla evento com as questões de sustentabilidade: "o SWU é a maior prova disto, ele deixou de acontecer, pois era muito radical na questão de sustentabilidade e público não aceitou muito bem a proposta" (ENTREVISTADA, 2014).

Com este mesmo raciocínio Zanella (2012) indica que um evento geralmente provoca fortes emoções para os participantes, para os promotores e organizadores e, enfim, para todos que convivem com um turbilhão de atividades que compõem seu universo. Para quem organiza, evento significa muito trabalho, iniciativa, criatividade, competência e resultado. Para quem participa, significa congraçamento e integração, gerando e consolidando vínculos e relações de caráter profissional e pessoal.

Na percepção da Entrevistada o evento precisa ter simbolismos e cuidados que estejam no cotidiano das pessoas. Citou como exemplo uma ação simples no evento "Festival Terra", que acontece em São Paulo, em que os próprios patrocinadores oferecem na entrada do evento um "porta bitucas" de cigarros, onde as pessoas depositam os restos do cigarro dentro de um recipiente e fecham, fazendo um descarte correto. Outro exemplo citado foi que no Evento $X$ existem áreas exclusivas destinadas para fumantes e dentro da área VIP é proibido fumar, pois possui muitos tecidos e carpetes.

Neste contexto Rogers e Martins (2011) apontam que a cada dia, os termos "responsabilidade socioambiental" e "sustentabilidade" também se tornam referência para o mundo corporativo brasileiro, no qual os eventos se inserem. Os

ReMAS - Revista Metodista de Administração do Sul, v. 2, N. 2, 2017 
eventos são muito variados e de muitos segmentos econômicos. Completando esta ideia, Matias (2011) afirma que:

A fase mais importante na criação de um evento verde é a fase do planejamento. É nessa etapa que as decisões serão previstas, portanto, a opção de realizar um evento sustentável deve ser definida no briefing, levantando todas as necessidades para atingir o objetivo da sustentabilidade e, a partir desses levantamentos, estabelecer estratégias e ações necessárias para sua execução (MATIAS, 2010, p.190).

Quando questionado sobre o interesse dos patrocinadores por ações de sustentabilidade desenvolvidas para eventos, a Entrevistada respondeu que no ponto de vista de comercialização as ações de sustentabilidade no evento não são determinantes para fechamento do negócio, mas sim para a parte institucional dos patrocinadores, de serem reconhecidos como uma marca do bem, uma marca "limpa" e preocupada com o meio ambiente, agregando mais valores institucionais. Completando esta ideia, Matias (2011) realça que:

A mitigação de impactos ambientais passou a ser levada a serio por diversos setores da economia mundial. Essa pratica já é vista como marketing positivo: as empresas procuram ter seus nomes associados a ações que buscam salvar o planeta. O setor de eventos, por prestar serviços a uma infinidade de segmentos, é mais um ator multiplicador dessas ações mitigatórias nas mais diversas esferas da sociedade (MATIAS, 2011, p.189).

Também foi abordada a opinião da gestora quanto ao interesse do público pela sustentabilidade. Na percepção da Entrevistada, o público tem interesse, ainda sutil, mas tem aceitado as ações de sustentabilidade em festivais como o Rock in Rio, o Terra, Lollapalooza, que são eventos que não tem ações radicais e sim ações que o público aceita bem. Por exemplo, no Evento $X$ "existem diversos banheiros químicos, tonéis de lixo espalhados por todo evento, são pequenos ges- 
tos mas que tem uma aceitação bastante grande pelo público" (ENTREVISTADA, 2014).

Para identificar os impactos ambientais que o evento pesquisado causou em uma determinada região e quais as ações necessárias para minimizá-los na visão do gestor do evento, foram elaboradas cinco perguntas dirigidas à Entrevistada, sendo que a primeira questão buscou verificar se a organização do evento faz um levantamento prévio dos possíveis impactos ambientais causados durante a realização. A Entrevistada respondeu positivamente, explicando que é realizado um check list, e que estas ações já estão internalizadas na realização do Evento $X$, uma vez que o mesmo se realiza a muito tempo no mesmo local. Completando esta ideia Matias (2011) diz que quando o setor de eventos e, principalmente, seus organizadores, investidores e patrocinadores acreditarem realmente na importância e abrangência da sustentabilidade e em seus diferenciais, ocorrerá a mudança de paradigmas de um setor importante, gerador de grande impacto, e capaz de promover melhorias sociais e ambientais que perdurem.

Em seguida, se buscou saber quais são estes impactos. A Entrevistada respondeu que são impactos diretamente e indiretamente causados pelo descarte correto dos resíduos gerados antes, durante e depois do evento e com a mobilidade urbana em torno do evento.

Perguntada sobre a questão das ações feitas pela organização do Evento $X$ para minimizar os impactos ambientais, a Entrevistada destacou o compromisso da empresa com a destinação correta dos resíduos, sendo feito a separação, reciclagem e doação para uma ONG de todo o lixo gerado. A reciclagem do óleo utilizado na praça de alimentação, o cuidado com a utilização dos geradores a óleo diesel para que os fluídos não tenham contato com o solo, as áreas exclusivas para fumantes, a reconstrução do solo com o plantio de novas

ReMas - Revista Metodista de Administração do Sul, v. 2, N. 2, 2017 
mudas de grama nos locais que recebem as estruturas de palco mais pesadas, a neutralização do carbono através do replantio de árvores de acordo com a emissão de poluentes, a doação ou venda das estruturas metálicas, para empresa metalúrgica que poderá absorvê-las ou transformá-las novamente em aço utilizável, além da acessibilidade para portadores de deficiência física, está restrita a área VIP do evento.

A Entrevistada ainda revelou que é realizado um workshop de educação ambiental para a equipe envolvida no evento, e que são tomados muitos cuidados com as questões da mobilidade urbana, com orientações quanto à logística no entorno do evento, são exemplos de práticas habituais da produção do evento. Neste pensamento, Matias (2011) refere que muitos eventos vêm investindo em ações de melhoria social ou ambiental de forma regular, tentando se posicionar como mais sustentáveis. Entretanto, são pouquíssimos os casos de eventos que se preocupam realmente com a questão da sustentabilidade, desde sua concepção, de forma integrada, buscando inserir melhorias e ações de redução de impactos em todos os aspectos do evento, desde a pré-produção até sua desmontagem.

Foi questionado se há algum órgão regulador ou fiscalizador que acompanha o evento. A Entrevistada respondeu a Brigada Ambiental realiza a fiscalização e controle do Evento X.

A última questão buscou identificar se há alguma parceria do evento com organizações públicas ou privadas para a minimização dos impactos. A Entrevistada respondeu que não existe uma parceria, mas sim um acompanhamento dos órgãos fiscalizadores quanto a questão da organização do evento.

\section{CONSIDERAÇÕES FINAIS}

Este artigo se propôs a identificar o perfil do público de um grande evento, as ações do planejamento de um evento sustentável ambientalmente na opinião de um gestor de eventos e 
por fim estudou os impactos ambientais que um grande evento proporciona na região em que é realizado e as ações sustentáveis que podem minimizá-los na visão do gestor de eventos.

Em relação ao perfil dos participantes do evento, conclui-se que a maioria é de jovens de 15 a 25 anos, tendo em seu gênero um maior número de mulheres, perfazendo $65 \%$ contra $34 \%$ de homens, onde a maioria é de estudantes com ensino médio completo e quase a totalidade mora no Rio Grande do Sul. Este público na sua grande maioria sabe o que é sustentabilidade, mas poucos têm contato com este tema quando o assunto é grandes eventos. Dentre os eventos mais citados pelos entrevistados estão o Planeta Atlântida em primeiro, Rock in Rio em segundo, SWU em terceiro, Lollapalooza em quarto e Coachela em quinto.

Com relação as ações do planejamento de grandes eventos para que se tornem ambientalmente sustentáveis na opinião de um gestor de grandes eventos, a pesquisa mostrou que há um movimento das organizações para que o assunto sustentabilidade esteja cada vez mais inserido dentro do escopo de trabalho. No entanto, a percepção sobre sustentabilidade dentro de eventos por parte do público, ainda não se faz tão presente e não serve como fator determinante na escolha de qual evento participar, pois a falta engajamento por parte do público que frequenta este tipo de atividade.

Também foram identificados os impactos ambientais que um grande evento proporciona na região em que é realizado e as ações que podem minimizá-los na visão de um gestor de grandes eventos. Dentro deste objetivo notou-se que existem diversas maneiras de diminuir os impactos ambientais nos eventos com ações do tipo: replantio de árvores para neutralizar o carbono, separação e destinação correta dos resíduos gerados pelo evento, o incentivo ao uso do transporte público, áreas exclusivas para fumantes, entre outros pontos observados na 
pesquisa. Estas tentativas de diminuição do impacto ambiental são vistas pelo mercado como uma ação positiva, atrativa de investidores e de conscientização do público em geral.

\section{REFERÊNCIAS}

ALLEN, Johnny. Organização e gestão de eventos. São Paulo:Campus, 2003.

ARANTES, Bernardo; ZANIN, Maria; FONTES, Nadia. Eventos mais sustentáveis: uma abordagem ecológica, econômica, social, cultural e política. São Carlos (SP): EDUFSCAR, 2008.

BARBIERI, José Carlos. Gestão ambiental empresarial: conceitos, modelos e instrumentos. São Paulo: Saraiva, 2007.

BATALHA, Ricardo. AC/DC, Ozzy Osbourne, Iron Maiden, Scorpions, Whitesnake, Queen e Yes juntos na "Cidade do Rock". Rock on line, [s.l], 15 mar 2000. Especiais: 15 anos de Rock in Rio. Disponível em: <http://territorio.terra. com.br/canais/rockonline/materias/materia.asp? $\operatorname{cod}$ Area $=3 \&$ materiaID $=182>$. Acesso em: 28 mar. 2014.

BELINKY, Aron; ECHEGARAY, Fabián; MATTAR, Helio; RODRIGUES, Geisa; VELHO, Christina. Pesquisa no. 7 - 2006: Como e por que os brasileiros praticam o consumo consciente? São Paulo, 2007. Disponível em: http:// www.akatu.org.br/Content/Akatu/Arquivos/file/Publicacoes/4-Pesquisa7. pdf. Acesso em: 20 set. 2013

CONTRERA, Malena Segura; MORO, Marcela. Vertigem mediática nos megaeventos musicais. Revista da Associação Nacional dos Programas de Pós-Graduação em Comunicação | E-compós, Brasília, v.11, n.1, jan./abr. 2008. Disponível em: < http://www.compos.org.br/seer/index.php/e-compos/ article/viewFile/221/262>. Acesso em: 12 maio 2014.

DINIZ, Elba Simone de Arêdes. Eventos verdes e sustentáveis: como operacionalizar ações práticas para minimizar os impactos dos eventos sem perder o melhor da diversão. In: CONGRESSO NACIONAL DE EXCELÊNCIA EM GESTÃO, 12., 2011, Rio de Janeiro. Anais... Rio de Janeiro, 2011. Disponível em: www.excelenciaemgestao.org/Portals/2/.../cneg7/.../T11_0354_2147.pdf®. Acesso em: 20 set. 2013

FEITOSA, Mardem. Os jovens e o tema de sustentabilidade: um estudo de caso sobre a percepção e a consciência de alunos de graduação de Administração de Empresas. In: ENCONTRO DA ANPAD., 2011, Rio de Janeiro. [Resumos...] Rio de Janeiro, 2011. Disponível em:< http://www.anpad.org. 
br/diversos/trabalhos/EnANPAD/enanpad_2011/EPQ/2011_EPQ2013.pdf>. Acesso em: 12 maio 2014.

FUNDAÇÃO INSTITUTO BRASILEIRO DE GEOGRAFIA E ESTATÍSTICA. Pesquisa mensal de emprego estimativas para o mês de janeiro de 2014 regiões metropolitanas de: Recife, Salvador, Belo Horizonte, Rio de Janeiro, São Paulo e Porto Alegre. Rio de Janeiro, 2014. Disponível em: <ftp://ftp.ibge. gov.br/Trabalho_e_Rendimento/Pesquisa_Mensal_de_Emprego/fasciculo_indicadores_ibge/2014/pme_201401pubCompleta.pdf>. Acesso em: 12 abr. 2014.

GIACAGLIA, Maria Cecília. Organização de Eventos: Teoria e Prática. São Paulo: Pioneira Thomson Learning, 2003.

GIL, Antonio Carlos. Como Elaborar Projetos de Pesquisa. São Paulo: Atlas, 2010.

LAVILLE, Élisabeth. A empresa verde. São Paulo: Õte, 2009.

LIMA, Paulo Rogério dos Santos. Responsabilidade Social: A experiência do Selo Empresa Cidadã na cidade de São Paulo - 1999. São Paulo: Puc-SP, 2005

MAKOWER, Joel. A economia verde: descubra as oportunidades e os desafios de uma nova era dos negócios. São Paulo: Gente, 2009.

MARCONI, Marina de Andrade; LAKATOS, Eva Maria. Fundamentos de Metodologia cientifica. São Paulo: Atlas, 2010.

MATIAS, Marlene. Planejamento, Organização e Sustentabilidade em Eventos: Culturais, Sociais e Esportivas. São Paulo: Manole, 2011.

MELLO, Zuza Homem de. A Era dos festivais: uma parábola. São Paulo: Editora 34, 2003.

MELO NETO, Francisco Paulo de. Criatividade em eventos. São Paulo: Contexto, 2000.

MOURA, Luiz Antônio Abdalla de. Qualidade e Gestão Ambiental. São Paulo: Editora Juarez de Oliveira, 2004.

PÁDUA, Elisabete Matallo Marchesini. Metodologia da Pesquisa: Abordagem Teórico prático. São Paulo: Papirus, 2004.

PAIVA, Hélio Afonso Braga de; NEVES, Marcos Fava. Planejamento estratégico de eventos: como organizar um plano estratégico para eventos turísticos e empresas de eventos. São Paulo: Atlas, 2008.

PETITINGA; Carolina Santos. Festival de verão Salvador: significado para o turismo, a música independente, a economia e o marketing da cidade. 2008, Salvador. Dissertação (Mestrado) - Universidade Federal da Bahia,

ReMAS • Revista Metodista de Administração do Sul, v. 2, N. 2, 2017 
Salvador. 2008. Disponível em: <https://repositorio.ufba.br/ri/bitstream/.../ dissert_Carolina\%20Petitinga.pdf $>$. Acesso em: 25 abr. 2014

RESULTADOS - questionário sobre o perfil do festivaleiro português e ambiente social nos festivais de música em Portugal. In: FORUM SOBRE O FUTURO DOS FESTIVAIS DE MÚSICA EM PORTUGAL - TALK FEST, 14., [2014], [Lisboa]. Disponível em: <https://www.dropbox.com/s/i1vzi8i5uc70gqz/ApresentacaoResultados_Quest.pdf>. Acesso em: 30 mar. 2014

ROBLES JR., Antônio; BONELLI, Valério Vitor. Gestão da qualidade e do meio ambiente: enfoque econômico, financeiro e patrimonial. São Paulo: Atlas, 2010.

ROGERS, Tony; MARTIN, Vanessa. Eventos: planejamento, organização e mercados. Rio de Janeiro: Elsevier, 2011.

SUSTAINABILITY Reporting Guidelines \&Event Organizers Sector Supplement. s.1: EOSS, 2012. Disponível em: https://www.globalreporting.org/ resourcelibrary/EOSS-G3.1-Complete.pdf. Acesso em 21 set. 2013.

SUSTENTABILIDADE: Em busca de eventos verdes e sustentáveis. Disponível em:< http://www.akatu.org.br/Temas/Sustentabilidade/Posts/Em-busca-de-eventos-verdes-e-sustentaveis\#sthash.ypbgVWTD.dpuf $>$ Acesso em 07 nov. 2013

SWU Music and Arts. Relatório de Sustentabilidade SWU 2010. s.l, 2010. Disponível em: http://www.swu.com.br/wp-content/uploads/2011/06/Relatorio_SWU_GRI.pdf. Acesso em: 20 set. 2013.

TACHIZAWA, Takeshy. Gestão ambiental e responsabilidade social corporativa: estratégias de negócios focadas na realidade brasileira. São Paulo: Atlas, 2006.

ZANELLA, Luiz Carlos. Manual de organização de eventos: planejamento e operacionalização. São Paulo: Atlas, 2012.

ZOBARAN, Sergio. Evento é assim mesmo! Do conceito ao brinde. Rio de Janeiro: SENAC, 2004. 